\title{
Cereal aphids (Hemiptera: Aphidoidea) in Serbia: Seasonal dynamics and natural enemies
}

\author{
Želiko TOMANOViĆ ${ }^{1}$, Nickolas G. KAVALlieratos ${ }^{2}$, Petr STARÝ ${ }^{3}$, Olivera PETROVIĆ-OBRAdOViĆ ${ }^{4}$, \\ CHRISTOS G. ATHANASSIOU ${ }^{5}$ and LJUBIŠA Ž. STANISAVLJEVIĆ ${ }^{1}$
}

${ }^{1}$ Institute of Zoology, Faculty of Biology, University of Belgrade, Studentski trg 16, 11000 Belgrade, Serbia; e-mail: ztoman@bf.bio.bg.ac.yu

${ }^{2}$ Laboratory of Agricultural Entomology, Department of Entomology and Agricultural Zoology, Benaki Phytopathological Institute, 8 Stefanou Delta str., 14561, Kifissia, Attica, Greece

${ }^{3}$ Institute of Entomology, Academy of Sciences of the Czech Republic, Branišovská 31, 37005 České Budějovicé, Czech Republic

${ }^{4}$ Department of Plant Protection, Faculty of Agriculture, University of Belgrade, Nemanjina 6, 11081, Zemun, Serbia

${ }^{5}$ Laboratory of Agricultural Zoology and Entomology, Agricultural University of Athens, 75 Iera Odos str., 11855, Athens, Attica, Greece

Key words. Cereal aphids, parasitoids, predators, seasonal dynamics, Serbia

\begin{abstract}
During 1989-2006 the number of live aphid, mummies, aphid specialist predators and their parasitoids in cereal fields in Serbia were recorded. S. avenae and M. dirhodum were the most common, both on wheat and rye crops. Maximum numbers of cereal aphids were detected between the end of May and the middle of June. A low percentage of mummified aphids was recorded during May and June, but increased rapidly at the beginning of July, when aphids left the wheat crop. Here, we record over 60 species of cereal aphid natural enemies, including primary and secondary parasitoids, aphid specific predators and a wide spectrum of their parasitoids in Serbian cereal crop systems. Aphidius uzbekistanicus Luzhetzki, Aphidius rhopalosiphi De Stefani, Aphidius ervi Haliday and Praon gallicum Starý were the most abundant species of primary parasitoids. Of the secondary parasitoids, six species were dominant with Asaphes suspensus (Nees) and Dendrocerus carpenteri (Curtis) generally the most often recorded. Coccinella septempunctata L. was the most abundant coccinellid and syrphid flies were represented by 11 species, two of which, Sphaerophoria scripta (L.) and Episyrphus balteatus (DeGeer), were the most common.
\end{abstract}

\section{INTRODUCTION}

Cereal agroecosystems make up about 600,000 ha in Serbia, and cereals are one of the most common crops. Cereal aphids are one of the most important insect pests limiting cereal production worldwide (Vickerman \& Wratten, 1979; Dixon, 1987; D’Arcy \& Mayo, 1997). Species composition, seasonal dynamics and pest status of cereal aphid species depend on the region and are influenced by a complex of factors (climate, biotype status, seasons, life cycles, agrotechnical practices, natural enemies) (Vickerman \& Wratten, 1979; Dean et al., 1981; Plantegenest et al., 1996; Brewer \& Elliott, 2004). Although, there are many publications on the seasonal occurrence of cereal aphids there are few for the region of southeastern Europe. The seasonal distribution of cereal aphids is affected by climatic conditions and biotic factors such as host plant quality, dispersal efficiency and natural enemies (Mann et al., 1995; Roitberg et al., 1979). Knowledge of the seasonal dynamics of cereal aphids at the field scale could be important for pest management purposes (Winder et al., 1999). Thies et al. (2005) concluded that cereal aphid-parasitoid interactions are affected by processes acting at the landscape scale, rather than that of individual habitats. The most important cereal aphids in Serbia are Sitobion avenae (F.), Metopolophium dirhodum (Walker) and Rhopalosiphum padi
(L.) (Petrović, 1996). Petrović (1996) also records Metopolophium festucae (Theobald), Sitobion fragariae (Walker), Rhopalosiphum maidis (Fitsch) and Sipha maydis Passerini. Diuraphis noxia (Kurdjumov) occurs sporadically in Serbian wheat fields (Petrović, 1992, 1996; Starý et al., 2003).

The important natural enemies of cereal aphids are parasitoids, predators and entomopathogenic fungi. Their economic importance is determined by their impact on cereal aphid populations in various regions/countries (Adisu et al., 2002). Cereal aphid communities are characterized by numerous trophic interactions with their natural enemies (parasitoids and predators) (Jones, 1972; Pankanin-Franczyk \& Ceryngier, 1995; Lumbierres et al., 2007). The literature provides a lot of information on the trophic interactions between cereal aphids and particular groups of natural enemies, of which only a few well known taxa are well studied (Sloggett, 2005). In this paper we record the diversity of cereal aphid natural enemies, including primary and secondary parasitoids, predators and their specific parasitoids, and assess their possible importance in cereal aphid communities. Furthermore, the seasonal dynamics of cereal aphids was studied in selected experimental wheat and rye fields in Serbia and the rate of mummification of the main cereal aphid species during 2004-2006 was recorded. 


\section{MATERIAL AND METHODS}

Samples were collected in cereal fields in Surcin $\left(44^{\circ} 46^{\prime} 12^{\prime \prime} \mathrm{N}, \quad 20^{\circ} 18^{\prime} 55^{\prime \prime} \mathrm{E}\right)$, Kovilovo $\left(44^{\circ} 54^{\prime} 08^{\prime \prime} \mathrm{N}, \quad 28^{\circ} 27^{\prime \prime}\right.$ $\left.49^{\prime \prime} \mathrm{E}\right)$, Obrenovac $\left(44^{\circ} 39^{\prime} 56^{\prime \prime} \mathrm{N}, 20^{\circ} 12^{\prime} 56^{\prime \prime} \mathrm{E}\right)$ and Galovica $\left(44^{\circ} 47^{\prime} 21^{\prime \prime} \mathrm{N}, 20^{\circ} 21^{\prime} 20^{\prime \prime} \mathrm{E}\right)$. These specific areas were chosen after sampling in previous years had indicated they were usually heavily infested with cereal aphids. All the fields are situated on the southeastern edge of the Pannonian plain, which is characterized by a central European lowland climate and vegetational structure (Janković et al., 1984). The area is characterized by relatively low humidity and a wide seasonal temperature range (summer-winter). The most diverse and widely distributed vegetal and ruderal weed plant communities in the northern agricultural lowland of Serbia (Vojvodina) are HibiscoEragrostietum megastachyae, Panico-Portulacetum oleraceae and Arctio-Artemisietum vulgaris (Janković et al., 1984). The experimental wheat fields (Surcin, Kovilovo, Obrenovac 1989-1990) were sampled to determine the abundance of (I) parasitoids and hyperparasitoids of cereal aphids, and (II) cereal aphid specialist predators and their parasitoids. The experimental wheat fields (Surcin 2004-2006) and those of rye (Galovica 2004-2005) were sampled to determine (I) the seasonal dynamics and mummification rate of cereal aphids, and (II) the abundance of cereal aphid specialist predators and their parasitoids. Samples in 1989-1990 were collected weekly from April till June. One hundred stems, $20 \mathrm{~cm}$ long, were randomly collected at each sampling date at least $50 \mathrm{~m}$ from the edge of the fields. Samples in 2004-2006 were collected weekly, from May till July at Surcin and Galovica from 10 preselected sites, $20 \mathrm{~m}$ apart, within each field (two rows with five sites in each row). From each site, 10 stems, $20 \mathrm{~cm}$ long (Kavallieratos et al., 2002), were collected on each sampling date at least $50 \mathrm{~m}$ from the field edge. All fields were approximately 5-6 ha, quadrate or subquadrate, not sprayed with insecticides and with 500-600 plants $/ \mathrm{m}^{2}$. Each stem was placed separately in a plastic bag and then cut from the plant using scissors. The bags were deposited into a portable refrigerator and brought to the laboratory where aphids were identified to species. Living aphids were preserved in a 2: 1 ratio of $90 \%$ ethyl alcohol and $75 \%$ lactic acid (Eastop $\&$ van Emden, 1972). Mummies were placed separately in small plastic boxes. Each box was labelled with the collection date and the serial number of the leaf. These plastic boxes were placed in a growth cabinet until adult parasitoid or hyperparasitoid emergence. There was a circular opening covered with muslin in the lid of each box for ventilation, which maintained conditions inside the boxes similar to that in the growth cabinet $\left(22.5^{\circ} \mathrm{C}, 65 \% \mathrm{RH}, 16 \mathrm{~L}: 8 \mathrm{D}\right)$.

The mean number of aphids per stem and the percentage of mummified aphids (of the total number of aphids) were calculated for each sampling date (Kavallieratos et al., 2005).

Aphids and their parasitoids were identified to species. Pupal and adult stages of aphid specialist predators were collected from the aphid samples. They were also put in the growth cabinet, as above, in order to obtain their specific parasitoids. The identification of parasitoids, hyperparasitoids, syrphids and chrysopids to species was done on adults. The coccinellids were identified to species at the pupal and adult stage.

\section{RESULTS}

\section{Species composition of aphids and their seasonal dynamics}

A total of 1806 aphids were found, of which S. avenae and $M$. dirhodum were the most common on wheat and rye crops (Fig. 1). The species composition, however, dif-

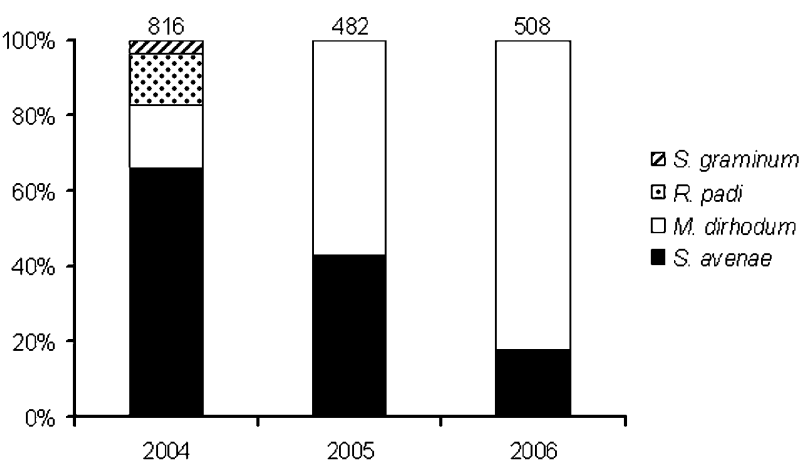

Fig. 1. Relative abundance of the aphid species (\%) (Sitobion avenae, Metopolophium dirhodum, Rhopalosiphum padi, Schizaphis graminum) on cereals in 2004, 2005 and 2006. The numbers (above the columns) are the total numbers of aphids collected from all the fields each year.

fered between years, with $S$. avenae being the most common aphid in $2004(66.18 \%)$, declining in 2005 (42.74\%) and 2006 (18.11\%), while M. dirhodum was most common species in 2006 (81.89\%) (Fig. 1).

In Fig. 2 we present the seasonal dynamics of aphids on wheat (Fig. 2a, d, e) and rye (Fig. 2b, c) at two localities in Serbia during 2004-2006. In 2004, the maximum numbers of $S$. avenae and Schizaphis graminum (Rondani) were found on rye at the beginning of June, with $1.00 \pm$ 0.18 and $0.42 \pm 0.41$ aphids per stem, respectively (Fig. 2b). M. dirhodum had a weak peak in abundance at the end of May, with only $0.33 \pm 0.32$ aphids per stem (Fig. $2 b)$. There were low numbers of $R$. padi on rye during the whole season in 2004. During 2005, only $S$. avenae and $M$. dirhodum were recorded on rye, with the first $S$. avenae detected at the end of May and M. dirhodum at the beginning of June (Fig. 2c). Both species peaked in numbers in the middle of June, with $0.65 \pm 0.16$ aphids per stem for $S$. avenae and $0.92 \pm 0.16$ aphids per stem for $M$. dirhodum (Fig. 2c). On wheat in 2005 (Fig. 2d) $S$. avenae reached a peak in abundance in the second half of June, followed by $M$. dirhodum, with maximum numbers of $1.00 \pm 0.22$ and $1.56 \pm 0.69$ aphids per stem, respectively. On wheat in 2006 (Fig. 2e) M. dirhodum peaked in abundance at the end of May (1.49 \pm 0.32 aphids per stem) and $S$. avenae in the second half of June $(0.55 \pm$ 0.26 aphids per stem).

\section{Species composition of primary and secondary aphid parasitoids and rate of mummification}

Among the primary parasitoids, the most abundant were generally Aphidius uzbekistanicus Luzhetzki, A. ervi Haliday, A. rhopalosiphi De Stefani and Praon gallicum Starý (Fig. 3). In contrast, Ephedrus plagiator (Nees) and Praon volucre (Haliday) were much less common (Fig. 3). A. uzbekistanicus (39.68\%) and A. ervi (33.51\%) were the dominant parasitoids of $S$. avenae, and A. rhopalosiphi (33.91\%) and P. gallicum (39.57\%) of M. dirhodum (Fig. 3). P. gallicum (42.86\%) was the most abundant species parasitizing $R$. padi, and A. uzbekistanicus $(53.85 \%)$ was the dominant parasitoid of $S$. graminum from 1989-1990 (Fig. 3). Furthermore, Adialytus 


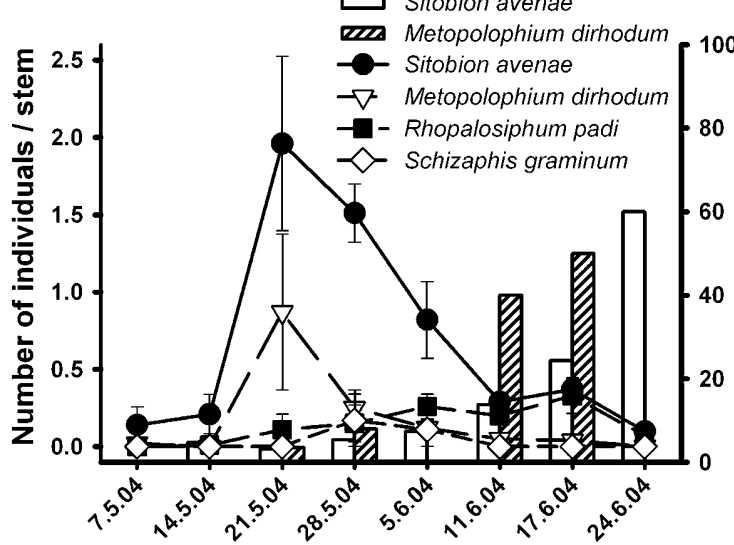

Date

c RYE

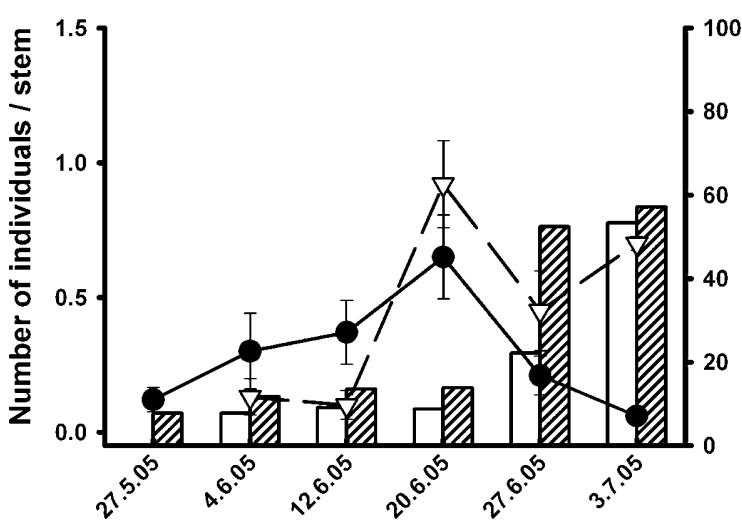

Date

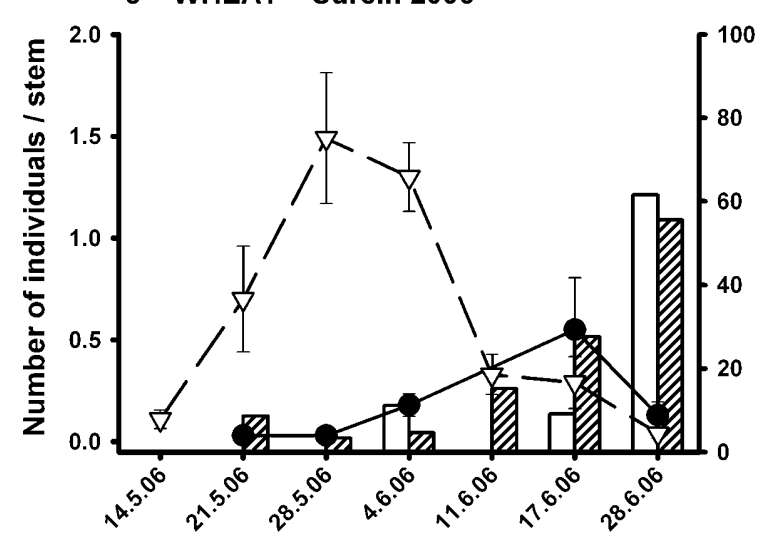

Date b RYE Galovica 2004

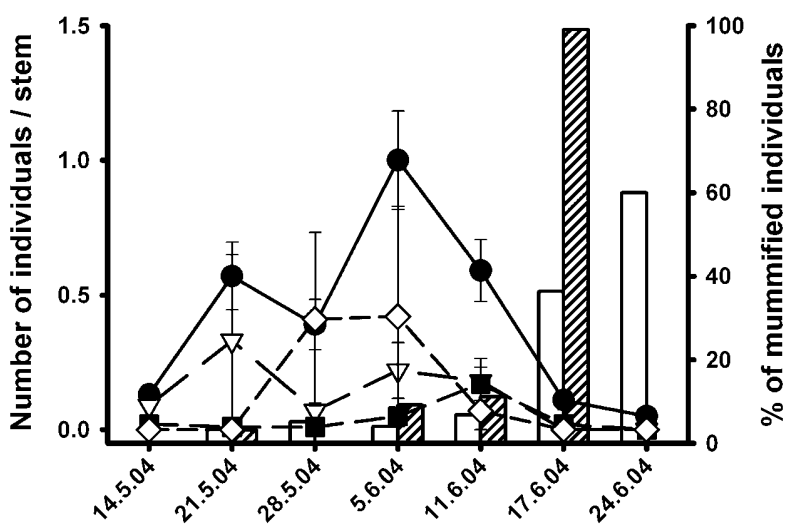

Date

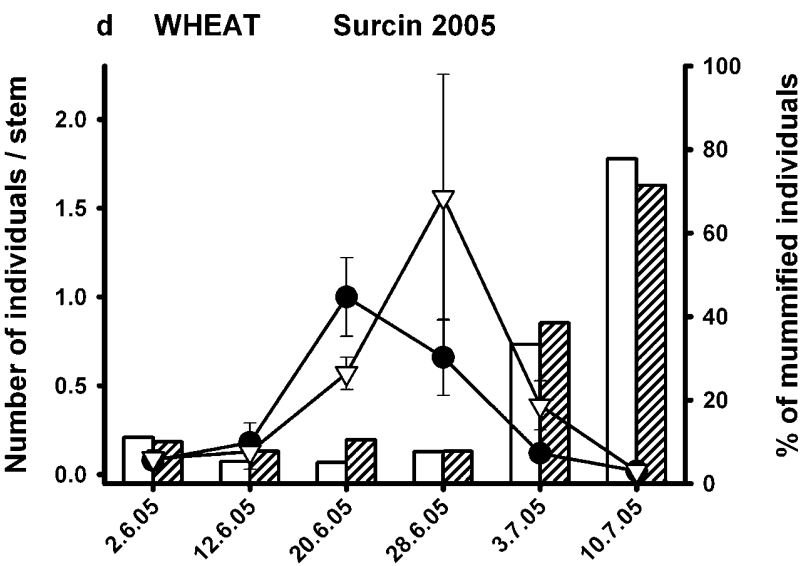

Date

Fig. 2. Mean ( $\pm \mathrm{SE})$ number of Metopolophium dirhodum, Rhopalosiphum padi, Schizaphis graminum, Sitobion avenae and percentage of mummified Metopolophium dirhodum and Sitobion avenae individuals on cereals in Serbia in 2004, 2005 and 2006. a - Surcin; b - Galovica; c - Galovica; d-Surcin; eSurcin.

(1 specimen), and $M$. dirhodum by $A$. abdominalis (2 specimens).

Of the hyperparasitoids, six species predominated with Asaphes suspensus (Nees) and Dendrocerus carpenteri (Curtis) generally the most abundant (Fig. 4). D. carpenteri $(42.05 \%)$ and $A$. suspensus $(30.57 \%)$ were the most

very low levels. $R$. padi was parasitized by Aphelinus varipes (Förster) (1 specimen), $S$. graminum by $A$. chaonia Walker (3 specimens) and A. abdominalis Dalman 


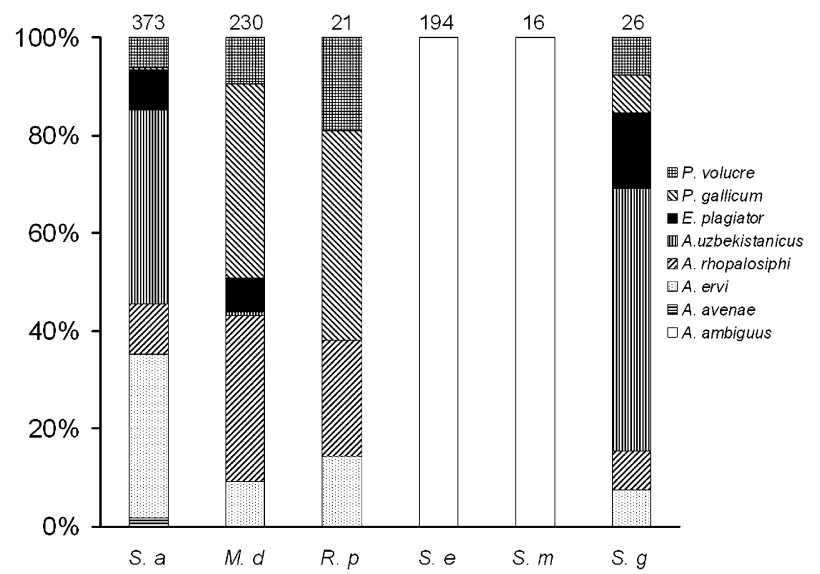

Fig. 3. Relative abundance of parasitoid species (\%) of Sitobion avenae (S. a), Metopolophium dirhodum (M. d), Rhopalosiphum padi (R. p), Sipha elegans (S. e), Sipha maydis $(S . m)$ and Schizaphis graminum (S. g) in 1989 and 1990. The numbers (above the columns) are the total numbers of aphidiine parasitoids that emerged from the aphids during 1989 and 1990.

abundant mummy hyperparasitoids of the most abundant aphid, S. avenae (Fig. 4). A. suspensus (51.03\%), D. carpenteri (11.11\%), Alloxysta victrix (Westwood) (9.88\%) and Asaphes vulgaris Walker (9.05\%) were the most common mummy hyperparasitoids emerging from $M$. dirhodum (Fig. 4). D. carpenteri (51.49\%) and A. suspensus $(30.69 \%)$ were the most abundant mummy parasitoids of

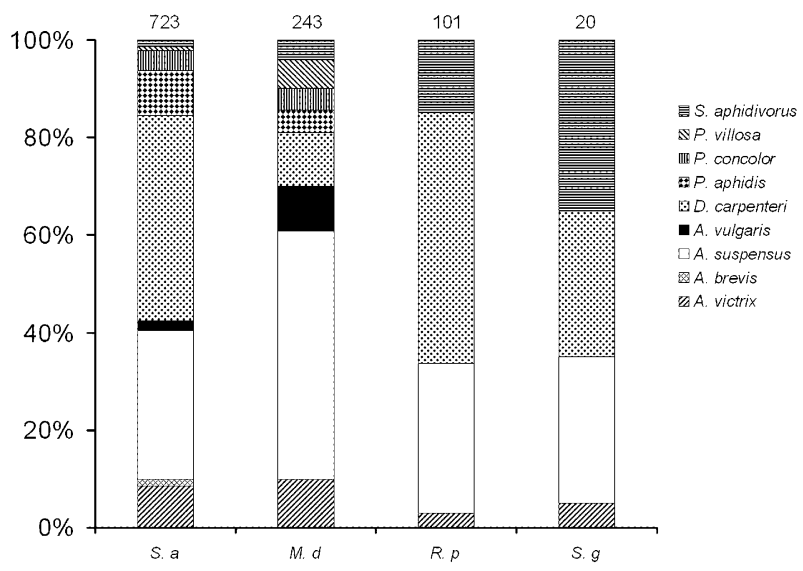

Fig. 4. Relative abundance of hyperparasitoid species (\%) of Sitobion avenae (S. a), Metopolophium dirhodum (M. d), Rhopalosiphum padi (R. p) and Schizaphis graminum $(S . g)$ in 1989 and 1990. The numbers (above the columns) are the total numbers of hyperparasitoids that emerged from the aphids during 1989 and 1990.

R. padi, and Syrphophagus aphidivorus (Mayr) (35.00\%), D. carpenteri (30\%) and A. suspensus (30\%) of S. graminum.

In 2004, a low rate of mummification of $S$. avenae and $M$. dirhodum was recorded at the end of May, which remained at $10 \%$ till the second half of June, when aphids left rye and the percentage of mummified $S$. avenae and

TABLE 1. Aphid specific predators and their parasitoids collected from cereal fields in Serbia in 1989, 1990, 2004, 2005 and 2006.

\begin{tabular}{|c|c|c|c|}
\hline \multicolumn{2}{|l|}{ Predators } & \multicolumn{2}{|l|}{ Parasitoids } \\
\hline Coleoptera: Coccinellidae & $\begin{array}{l}\text { Total number } \\
\text { of specimens }\end{array}$ & Parasitoids of Coccinella septempuncata L. & $\begin{array}{l}\text { Total number } \\
\text { of specimens }\end{array}$ \\
\hline Coccinella septempunctata $\mathrm{L}$. & 322 & Diptera: Phoridae & \\
\hline Adalia bipunctata $(\mathrm{L})$. & 17 & Phalacrotophora fasciata (Fallén) & 7 \\
\hline Adalia decempunctata (L.) & 2 & & \\
\hline Hippodamia tredecimpunctata (L.) & 5 & Hymenoptera: Eulophidae & \\
\hline Hippodamia variegata (Goetze) & 5 & Oomyzus scaposus (Thomson) & 16 \\
\hline Propylea quatuordecimpunctata (L.) & 9 & Aprostocetus neglectus (Domenicchini) & 5 \\
\hline Scymnus spp. & 1 & & \\
\hline \multirow[t]{2}{*}{ Diptera: Syrphidae } & & Parasitoid and hyperparasitoid complex of Syrphidae & \\
\hline & & Hymenoptera: Pteromalidae & \\
\hline Episyrphus balteatus (DeGeer) & 93 & Pachyneuron formosum Walker & 225 \\
\hline Melanostoma scalare (F.) & 1 & Pachyneuron umbratum Delucchi & 62 \\
\hline Metasyrphus corollae $\mathrm{F}$. & 15 & Pachyneuron spp. & 10 \\
\hline Metasyrphus latilunulatus (Collin) & 1 & Pteromalus spp. & 6 \\
\hline Paragus quadrifasciatus Meigen & 1 & Hymenoptera: Encyrtidae & \\
\hline Platycheirus fulviventris (Macquart) & 1 & Syrphophagus aeruginosus (Dalman) & 12 \\
\hline Sphaerophoria menthastri (L.) & 4 & Bothriothorax clavicornis (Dalman) & 2 \\
\hline Sphaerophoria rueppellii (Wiedemann) & 17 & Hymenoptera: Ichneumonidae & \\
\hline Sphaerophoria scripta (L.) & 135 & Promethes laetatorius (F.) & 36 \\
\hline Scaeva pyrastri (L.) & 36 & Promethes spp. & 6 \\
\hline \multirow{2}{*}{ Syrphus ribesii (L.) } & 1 & Syrphophilus spp. & 4 \\
\hline & & Syrphoctonus spp. & 3 \\
\hline \multirow[t]{2}{*}{ Neuroptera: Chrysopidae } & & Parasitoid complex of Chrysopidae & \\
\hline & & Hymenoptera: Eulophidae & \\
\hline \multirow{3}{*}{$\begin{array}{l}\text { Chrysopa carnea } \text { Stephens } \\
\text { Chrysopa perla }(\mathrm{L} .)\end{array}$} & 16 & Baryscapus impeditus (Nees) & 20 \\
\hline & 3 & Hymenoptera: Ichneumonidae & \\
\hline & & Dichrogaster longicaudata (Thomson) & 5 \\
\hline
\end{tabular}


M. dirhodum reached $60 \%$ and $100 \%$, respectively (Fig. 2b). In 2005, the percentage of parasitized aphids showed similar patterns to that in 2004 (Fig. 2c). In 2005, a low percentage of mummified aphids was observed during June, which increased rapidly at the beginning of July, when aphids migrated from wheat (Fig. 2d). In 2006 (Fig. 2e) the pattern of mummification on wheat was the same as in previous years.

\section{Aphid specific predators and their parasitoids}

Over the period 1989-2006 we collected and identified 685 individuals of aphid specific predators belonging to over 20 coccinellid, syrphid and chrysopid species (Table 1). Coccinella septempunctata $\mathrm{L}$. was the most abundant coccinellid (89.20\%) and only one pupa of this species was parasitized (Table 1). There were 11 species of syrphid flies, of which Sphaerophoria scripta (L.) (44.26\%) and Episyrphus balteatus (DeGeer) (30.49\%) predominated (Table 1). During the period 1989-1990 about 30\% of the syrphids were parasitized at the pupal stage, by a parasitoid complex consisting of over 10 species (Table 1), while in 2004-2006, this percentage was about $10 \%$. Furthermore, one hyperparasitoid, Syrphophagus aeruginosus (Dalman), was also recorded from syrhid pupae (Table 1). In total, 19 specimens of Chrysopa carnea Stephens and C. perla (L.) were identified. Two parasitoid species, Baryscapus impeditus (Nees) and Dichrogaster longicaudata (Thomson) emerged from pupae of these chrysopids (Table 1).

\section{DISCUSSION}

The parasitoid complex of cereal aphids in Serbia is similar to that found in the rest of Europe (Starý, 1976; Pankanin-Franczyk \& Ceryngier, 1995; Adisu et al., 2002; Sigsgaard, 2002; Lumbierres et al., 2007) but the abundance of the individual species is different. Surprisingly, D. noxia is rarely recorded in Serbia (Petrović, 1996), and neighboring parts of Hungary, but it is more abundant in Central Europe (Hungary, Austria, Slovakia, Czech Republic, Poland, Germany), where it is the dominant pest of barley even at high altitudes (Starý, 2000; Starý et al., 2003).

Our long term survey of primary parasitoids reveals that $A$. uzbekistanicus and A. ervi are the dominant parasitoid species of $S$. avenae. According to BilewiczPawinska \& Pankanin-Franczyk (1995) warm and dry climatic conditions affects the dominance of this species in Poland. Also, P. gallicum and A. rhopalosiphi are dominant parasitoid species of $M$. dirhodum and $R$. padi. In western and central Europe $P$. gallicum is rarely collected (Starý, 1976, Adisu et al., 2002) but was recently found for the first time on the Iberian Peninsula (Lumbierres et al., 2007). Additionally, Toxares deltiger (Haliday) is unrecorded in Serbia, despite a long term survey of parasitoids there. This species is known in Britain (Powell, 1982) and Poland (Pankanin-Franczyk \& Sobota, 1998). The other primary parasitoid species are also often recorded in Europe, with the exception of $A$. colemani. This species is used as a biocontrol agent in glasshouses and in the open field in several countries
(Starý, 2002). However, its establishement in the field was achieved either by direct introduction (Czech Republic) (Starý, 2002) or accidental escape from glasshouses (Germany) where it is now a dominant parasitoid of $M$. dirhodum (Adisu et al., 2002). However, in spite of its utilisation in glasshouses in several European countries $A$. colemani was not detected in cereal communities in Serbia. Although Aphelinus species are significant cereal aphid parasitoids in Spain (Lumbierres et al., 2007) and France (Hopper et al., 1995) we found few Aphelinus specimens in Serbia. Furthermore, parasitoids dominated over hyperparasitoids. Although, Alloxystinae hyperparasitoids are a very important part of this parasitoid assemblage in Central Europe (Höller et al., 1993; Pankanin-Franczyk \& Sobota, 1998; Adisu et al., 2002) a relatively low percentage was reared from mummies of $S$. avenae and $M$. dirhodum in this study. D. carpenteri and A. suspensus were the dominant species of hyperparasitoids, which accords with other records from Europe (Dean et al., 1981; Höller et al., 1993, Pankanin-Franczyk \& Sobota, 1998).

There is a wide spectrum of over 60 species of cereal aphid natural enemies (parasitoids and predators), in cereal crops communities in Serbia. Although the role of cereal aphid predators and primary and secondary parasitoids has been studied in different ways (Jones, 1972; Dean et al., 1981; Powell, 1982; Hellenius, 1990; Höller et al., 1993; Pike et al., 1997; Pankanin-Franczyk \& Sobota, 1998; Thies et al., 2005), the parasitoids of aphid specific predators are usually overlooked. Based on our findings of a wide spectrum of parasitoids of aphid specific predators, we conclude that they are an important factor reducing the abundance of predators and cannot be overlooked when considering the effectivity of predators in reducing cereal aphid densities. Gilbert (2005) pointed out that hyperparasitism of syrphid specific parasitoids is extremely rare and all the records are most probably accidental. We found only 12 specimens of S. aeruginosus, which is reported mainly as a secondary parasitoid of syrphids (Noyes, 2003). The effect of primary parasitoids on cereal aphids density was measured by the percentage of mummification. This was recorded during 2004-2006, when it was relatively low and rarely exceeded $10 \%$ at the study sites. However, the real measure of parasitoid effect is the aphid parasitization rate, which is significantly higher than the rate of mummification during the early stage of cereal aphid increase (Kuo-Sell \& Eggers, 1987). Patterns in the relationships between cereal aphids and their parasitoids, from various European countries, point to the importance of early parasitization of cereal aphids, which prevents their rapid increase. The high level of mummification when wheat is maturing is influenced by the emigration of aphids from cereals (Starý, 1976, 1978, 1981; Dedryver \& Gellé, 1982; Kuo-Sell \& Eggers, 1987; Pankanin-Franczyk \& Ceryngier, 1995; Adisu et al., 2002; Sigsgaard, 2002). Differences in the numbers of cereal aphids and their parasitoids between years and fields is influenced by the landscape (Schmidt et al., 2003; Thies et al., 2005). All the study sites were 
situated in extensive agricultural areas, but in landscape with different levels of complexity. The influence of the latter on cereal aphid numbers and their regulation by natural enemies is a subject of future research.

ACKNOWLEDGEMENTS. The research was partially supported by Grant 143006B (The Ministry of Science of the Republic of Serbia), Grant S5007102 (Grant Agency, Academy of Sciences of the Czech Republic) and by the Entomology Institute Project Z50070508 (Academy of Sciences of the Czech Republic).

\section{REFERENCES}

Adisu B., Starý P., Freier B. \& Büttner C. 2002: Aphidius colemani Viereck (Hymenoptera: Braconidae: Aphidiinae) detected in cereal fields in Germany. J. Pest Sci. 75: 89-94.

Bilewicz-Pawinska T. \& Pankanin-Franczyk M. 1995: The influence of environmental factors on parasitoids (Hymenoptera) in agroecosystems. Wiad. Entomol. 14: 103-111.

Brewer M.J. \& ElLIOTt N.C. 2004: Biological control of cereal aphids in North America and mediating effects of host plant and habitat manipulations. Annu. Rev. Entomol. 49: 219-242.

D'Arcy C.J. \& Mayo M. 1997: Proposals for changes in luteovirus taxonomy and nomenclature. Arch. Virol. 142: $1285-1287$

Dean G.J., Jones M.G. \& Powell W. 1981: The relative abundance of hymenopterous parasites attacking Metopolophium dirhodum (Walker) and Sitobion avenae F. (Hemiptera: Aphididae) on cereals during 1973-79 in southern England. Bull. Entomol. Res. 71: 307-315.

Dedryver C.A. \& Gellé A. 1982: Biologie des pucerons des céréales dans l'ouest de la France. IV - Étude de l'hivernation de populations anholocycliques de Rhopalosiphum padi (L.), Metopolophium dirhodum (Walker) et Sitobion avenae (F.), sur repousses de céréales, dans trois stations de Bretagne et du Bassin parisien. Acta Oecol. 3: 321-342.

Dixon A.F.G. 1987: Cereal aphids as an applied problem. Agr. Zool. Rev. 2: 1-57.

EASTOP V.F. \& VAN EMdEN H.F. 1972: The insect material. In van Emden H.F. (ed.): Aphid Technology. Academic Press, London, $45 \mathrm{pp}$.

Gilbert F. 2005: Syrphid aphidophagous predators in a food-web context. Eur. J. Entomol. 102: 325-333.

Helenius J. 1990: Incidence of specialist natural enemies of Rhopalosiphum padi (L.) (Homoptera: Aphididae) on oats in monocrops and mixed intercrops with faba bean. J. Appl. Entomol. 109: 136-143.

Höller C., Borgemeister C., Haardth H. \& Powell W. 1993: The relationship between primary parasitoids and hyperparasitoids of cereal aphids: an analysis of field data. J. Anim. Ecol. 62: 12-21.

Hopper K.R., Aidara S., Agret S., Cabak J., Coutinot D., Dabire R., Lesieux C., Kirk G., Reichart S., Tronchetti F. \& VIDAL J. 1995: Natural enemy impact on the abundance of Diuraphis noxia (Homoptera: Aphididae) in wheat in Southern France. Environ. Entomol. 24: 402-408.

Janković M., Pantić N., Mišić V., Diklić N. \& Gajić M. 1984: Vegetation of Serbia. Serbian Academy of Sciences, Belgrade, $408 \mathrm{pp}$.

JoNES M.G. 1972: Cereal aphids, their parasites and predators caught in cages over oat and winter wheat crops. Ann. Appl. Biol. 72: 13-25.

Kavallieratos N.G., Stathas G.J., Athanassiou C.G. \& PapaDOULIS G.T. 2002: Dittrichia viscosa and Rubus ulmifolius as reservoirs of aphid parasitoids (Hymenoptera: Braconidae:
Aphidiinae) and the role of certain coccinellid species. Phytoparasitica 30: $231-242$.

Kavallieratos N.G., Athanassiou C.G., Tomanović Ž., Sciaretta A., Trematerra P. \& ŽıIÍ́ V. 2005: Seasonal occurrence, spatio-temporal distribution and sampling indices for Myzus persicae (Sulzer) (Hemiptera: Aphidoidea) and its parasitoids (Hymenoptera: Braconidae: Aphidiinae) on tobacco. Eur. J. Entomol. 102: 459-468.

Kuo-Sell H.L. \& EgGers G. 1987: Evaluation of the effect of parasitoids on the population dynamics of cereal aphids by comparing the rates of mummification and parasitization in winter wheat. Z. Pflanzenkr. Pflanzenschutz 94: 178-189.

Lumbierres B., Starý P. \& Pons X. 2007: Seasonal parasitism of cereal aphids in a Mediterranean arable crop system. $J$. Pest Sci. 80: 125-130.

Mann J.A., Tatchell G.M., Dupuch M.J., Harrington R., Clark S.J. \& McCartney H.A. 1995: Movement of apterous Sitobion avenae (Homoptera: Aphididae) in response to leaf disturbances caused by wind and rain. Ann. Appl. Biol. 126: $417-427$.

NoYes J.S. 2003: Universal Chalcidoidea Database. World Wide Web Electronic Publication. www.nhm.ac.uk/entomology/chalcidoids/index.html.

Pankanin-Franczyk M. \& Ceryngier P. 1995: Cereal aphids, their parasitoids and coccinellids on oats in central Poland. $J$. Appl. Entomol. 119: 107-111.

PanKanin-Franczyk M. \& Sobota G. 1998: Relationships between primary and secondary parasitoids of cereal aphids. J. Appl. Entomol. 122: 389-395.

Petrović O. 1992: First contribution on Diuraphis noxia (Mordvilko) (Homoptera: Aphididae) in Serbia. Zašt. Bilja 43: 145-147.

Petrović O. 1996: Aphids (Homoptera: Aphididae) on cereal crops. Rev. Res. Work Fac. Agr. Belgrade 41: 159-168.

Pike K.S., Starý P., Miller T., Allison D., Boydston L., Graff G. \& Gillespie R. 1997: Small-grain aphid parasitoids (Hymenoptera: Aphelinidae and Aphidiidae) of Washington: distribution, relative abundance, seasonal occurence, and key to known North American species. Environ. Entomol. 26: 1299-311.

Plantegenest M., Pierre J.S., Caillaud C.M., Simon J.C., Dedryver C.A. \& Cluzeau S. 1996: A model to describe the reproductive rate in the aphid Sitobion avenae (Hemiptera: Aphididae): a case study. Eur. J. Entomol. 93: 545-553.

Powell W. 1982: The identification of hymenopterous parasitoids attacking cereal aphids in Britain. Syst. Entomol. 7: 465-473.

Roitberg B.D., Myers J.H. \& Frazer B.D. 1979: The influence of predators on the movement of apterous pea aphids between plants. J. Appl. Ecol. 48: 111-122.

Schmidt M.H., Lauer A., Purtauf T., Thies C., Schaefer M. \& TsChARNTKE T. 2003: Relative importance of predators and parasitoids for cereal aphids control. Proc. R. Soc. (B) 270: 1905-1909.

SigSGAARD L. 2002: A survey of aphids and aphid parasitoids in cereal fields in Denmark, and the parasitoids' role in biological control. J. Appl. Entomol. 126: 101-107.

SloggetT J.J. 2005: Are we studying too few taxa? Insights from aphidophagous ladybird beetles (Coleoptera: Coccinellidae). Eur. J. Entomol. 102: 391-398.

STARÝ P. 1976: Parasite spectrum and relative abundance of parasites of cereal aphids in Czechoslovakia (Hymenoptera: Aphidiidae, Homoptera: Aphidoidea). Acta Entomol. Bohemoslov. 73: 216-233.

STARÝ P. 1978: Seasonal relations between red clover, wheat, and barley agro-ecosystems through aphids and parasitoids 
(Hymenoptera: Aphidiidae, Homoptera: Aphidoidea). Acto Entomol. Bohemoslov. 75: 296-311.

StarÝ P. 1981: Biosystematic synopsis of parasitoids on cereal aphids in the western Palaearctic (Hymenoptera: Aphidiidae, Homoptera: Aphidoidea). Acta Entomol. Bohemoslov. 78: 382-396.

STARÝ P. 2000: On-going expansion of Russian wheat aphid, Diuraphis noxia (Kurdjumov) in central Europe (Homoptera: Aphididae). J. Pest Sci. 73: 75-78.

StarÝ P. 2002: Field establishment of Aphidius colemani Viereck (Hymenoptera: Braconidae: Aphidiinae) in the Czech Republic. J. Appl. Entomol. 126: 405-408.

Starý P., Basky Z., Tanigoshi L.K. \& Tomanović Ž. 2003: Distribution and history of Russian wheat aphid, Diuraphis noxia
(Kurdjumov) in the Carpathian Basin (Homoptera: Aphididae). J. Pest Sci. 76: 17-21.

Thies C., Roschewitz I. \& Tscharntke T. 2005: The landscape context of cereal aphid-parasitoid interactions. Proc. R. Soc. (B) 272: 203-210.

Vickerman G.P. \& Wratten S.D. 1979: The biology and pest status of cereal aphids (Hemiptera: Aphididae) in Europe: a review. Bull. Entomol. Res. 69: 1-32.

Winder L., Perry J.N. \& Holland J.M. 1999: The spatial and temporal distribution of the grain aphid Sitobion avenae in winter wheat. Entomol. Exp. Appl. 93: 277-290.

Received September 18, 2007; revised and accepted March 14, 2008 